\title{
Motivation of modern Ukrainian teachers' professional activities: generation archetypes
}

\author{
Liudmyla Kalashnikova ${ }^{1}$, and Iryna Hrabovets ${ }^{2, *}$ \\ ${ }^{1}$ Petro Mohyla Black Sea National University, Department of Sociology, 68 Marines Str., Mykolaiv, 54003, Ukraine \\ ${ }^{2}$ Kryvyi Rih State Pedagogical University, Department of Sociology and Economics, 54 Gagarina Ave., Kryvyi Rih, 50086, Ukraine
}

\begin{abstract}
The article gives an analysis of data of an All-Ukrainian Monitoring Survey conducted by the Ukrainian Educational Research Association using TALIS methodology among secondary school teachers to determine generation differences of professional activity motivation. According to the generation theory of W. Strauss and N. Howe, we implement the new variable "generation" into the empirical data in order to divide the selected cluster into homogeneous groups of representatives of the Silent Generation, Baby boomers, Generations $\mathrm{X}, \mathrm{Y}$, and $\mathrm{Z}$. To find the motivation for professional activity, we used the methodological approach of J. Barbuto and R. Scholl. Appealing to the concepts of V. Rozanov, Iu. Kuliutkin and V. Bezdukhov, the authors of the article attempted to determine motivation methods for professional activity for all generations of teachers.
\end{abstract}

\section{Introduction}

The reform of the national school education system provides its transformation in accordance with the needs of society and socio-economic opportunities of providing the functioning of the system in a certain period. Key figures of the changes are certainly teachers. Providing education quality starts with the formation of teachers' motivated professional activity because they must adjust themselves to dynamically changing socio-economic and sociocultural conditions of education. They also must master innovative education technology, enrich, re-estimate and produce new knowledge, determine their place in society, assume new social roles, and be qualified and professionally mobile.

In the opinion of V. Rozanov [14] the efficiency of motivation control depends on the possibility to implement the learner-centered approach, namely on the knowledge of needs and individual characteristics of employees, understanding of their goals, wishes and ambitions, usage of a wide number of encouraging methods in communication with them including kindness, tolerance, and ethics. By forming teachers' motivation, school headmasters have an opportunity to reach the goal of the school functioning, form its reputation and increase the working performance of the teaching staff in general.

Developing the concept of educational management L. Kalinina, L. Karamushka, T. Sorochan, R. Shyian [2] appeal to the opinion that every teacher has his/her own relatively stable system of professional activity motivation, depending on their worldview, orientation, traits of character, self-awareness, life and professional experience. Therefore, motivation control should include the formation of favorable conditions to activate their professional activity.

The relationship between teaching activity motivation and values is one of the most complex and interesting problems for education researchers. V. Yadov [3] was the first to study values as an independent component of teaching activity, determining them as the axis of consciousness of the teacher, around which his/her thoughts and feelings are grouped. Taking into account the fact that the hierarchy of these values influences the expansion of vital interests, it is the professional values of teachers' orientation that determine the degree of their activity, according to the highest needs for self-expression and self-improvement. However, I. Bekh claims that some teachers have anti-innovation barriers. They think and act stereotypically because they used toper form a significantly narrower range of tasks. Their attitude toward changes is not sensible enough and the internal motivation for their professional activity is rather low [4]. In the first place, the question here is in the relationship between values and motivation for professional activities of teachers belonging to different age groups.

Nowadays under the conditions of a systemic crisis in the country teachers-enthusiasts, whose choice of profession is motivated by high social significance must be adaptive, dynamic, ready for all kinds of innovations to be able to avoid the situations of functional illiteracy and professional incompetence. Within the scientific approach of Iu. Kuliutkin, V. Bezdukhov [5] propose to consider the combination of teacher experience and self-reflection as the leading

\footnotetext{
Corresponding author: 15srps2016@kdpu.edu.ua
} 
factors in the development of the education system. This approach emphasizes that knowledge of the leading motivation of professional activity and the hierarchy of personal values is an important but not sufficient condition to choose the best ways to encourage the teachers. Of extreme importance is how they perceive and evaluate certain situations and what they consider as expected of them.

In this sense, the need to determine the value differences among the representatives of various generations of teachers, the value points of their identification in order to avoid possible conflicts is relevant. In our opinion, that is why identification and analysis of differences in value systems, professional activity motivation and readiness for self-expression, self-improvement of representatives of different generations of teachers can define the range of possible problems on the way towards the formation of the new Ukrainian school and develop practical recommendations to improve the situation.

\section{Results and discussion}

According to the theory of W. Strauss, N. Howe [6] the values of representatives of different generations determined by the socio-economic conditions under which the personality and worldview of the generation representatives developed. Thus, the authors distinguishes among others the Silent Generation (people who were born in 1925-1942), the generation of Baby boomers (1943-1960), Generation X or the 13th Generation (1961-1981), Generation Y or Millennially (1982-2004), Generation Z or Homeland Generation (since 2005). Indicated periods are relative. A basic duration of influence and transformation is about 20 years, which corresponds to socially and biologically determined phases of human life. Created on the ground of archetypes, specific images always correlate with the dominant cultural program of a certain period producing them. Generations of the same archetype are united by the specifics of the historical location, initial experience and general characteristics at the individual and system levels as and the general configuration of the life.

W. Strauss, N. Howe paid special attention to the archetypes of generations (prophet, nomad, hero, artist) formed according to the "crisis-high-awakeningunraveling" cycles in the development of society [6]. The generation of prophets is born during the end of the crisis, thus they are characterized by morality and eccentricity. Born in the high cycle, the generation of nomads is distinguished by its rebelliousness, critical appraisal of the predecessors' activities, and pragmatic leadership. Heroes are born in the era of unraveling; they are characterizing by optimism, energy, individual pragmatism, and self-reliance. Then artists are born who get under hyper protection of their own predecessors. They are characterizing by individualism, adaptability, and aesthetics. Generations born in the eras of crisis and awakening are more active, independent, and become the driving force of historical events. Unlike them, those formed in the high and unraveling periods are considered as recessive, more adaptive to living conditions created by previous generations.

M. Titma [7] and B. Urlanis [8] carried out thorough researches of the generations' differences focused on the study of self-identification and values. Y. Levada investigated the characteristics of the age groups development and proved that the "generation gap" represents a split in the system of values, which takes place under certain circumstances of sociohistorical development [9]. Studying the social dynamics of post-Soviet societies, he concluded that the communities are characterized by inertness of social attitudes and values. It is demonstrated in consciousness change between generations and stereotyped behavior of the majority of representatives of these societies. According to the researcher, these trends considerably slow down the implementation of any reforms.

Analyzing the mentality types of different generations' representatives, V. Pischik highlighted their dominant values. Thus, in her opinion, representatives of the Silent Generation are characterized by loyalty, patience, honesty, and categoricalness, while Baby boomers are distinguished by optimism, collectivism, family orientation, and communication skills. Generation X is characterized by readiness to sacrifice, aesthetics of life, orientation towards common well-being, sociability, technical literacy, informality of views, heterogeneity, emotionality, and representatives of Generation $\mathrm{Y}$ are known by their innovative activity, naivety, hedonism, and the desire for quick reward. In contrast to its predecessors, Generation Z is self-centered and inattentive, but tolerant and fair at the same time, with its inherent "clip" thinking and short communications [10].

L. Novikova in her works adapted the theory of the generations of W. Strauss and N. Howe to Ukrainian reality appealing to the central events that occurred during the years of birth of the generations' representatives. She distinguished such generations as those who were born before the Second World War (1930-1939) (70-year-olds); 'post-war generation' (1950-1959) (50-year-olds); generation of the period of 'socialism stagnation' (1970-1979) (30-year-olds); generation of 'independence' (1989-1993) (20-yearolds) [1]. Analyzing the results of the World Values Survey 2011 (WVS) the author concluded that among other generations, the youngest generation born at the turning point of the Soviet era is especially noticeable because its representatives are characterized by a strongly marked intergenerational shift. Representatives of all four generations are united by the dominance of materialistic values, in particular, existential security and external authority. Unlike its predecessors, the generation of independence focuses on the development of their own abilities and competencies, considering them as a factor of wellbeing. Post materialistic values are prevalent for the group. Self-expression is less important for the Silent 
Generation than it is for Baby boomers and Generation $\mathrm{X}$.

Mentioning the archetypes of generations demonstrated in the motivation of the teachers' professional activities, we should note the fact that motivation is very closely related to values and value orientations as consciously chosen guidelines for activity. Values are formed in the process of personal development and active work; they also enable motivation control. Teacher performance is not determined by one specific motive; it is polymotivational in its nature. For the teacher activity there are internal (reward, approval, prestige, career growth, etc.) and external motivations (interest in professional growth, result orientation, selfdevelopment, etc.). Value motivation for an individual in education establishment acts both as an effective tool in staff management and as an instrument for achieving the educational process goals. At the present stage of development of the general secondary education with its focus on innovation activity, the motive for self-improvement and self-actualization as readiness for activity under new conditions becomes especially important.

To determine the peculiarities of the motivation for professional activity, readiness for self-expression and self-improvement of representatives of different generations of teachers, we carried out an analysis of the data of the All-Ukrainian Monitoring Survey. The Survey was conducted in February-August 2017 by the Ukrainian Educational Research Association using TALIS methodology among the secondary school teachers. The research sample consisted of 3,600 teachers in 5-9 grades of 201 Ukrainian secondary schools [11].

In an open database formed on the results of the survey and presented on the official website of the Ukrainian Association of Educational Researchers, among other personal data about survey participants, their age was indicated. It let us divide the sample into homotypic and homogeneous groups of representatives of the Silent Generation, Generations $\mathrm{X}, \mathrm{Y}$, and $\mathrm{Z}$ through the introduction of the additional variable. It is similar to the interpretation of the theory of the generations of W. Strauss and N. Howe (the groups account for $0.4 \%, 26.3 \%, 54.2 \%, 19.0 \%$, and $2 \%$ of the total sample size correspondingly) [6]. As for the peculiarities of professional activity, we should note that representatives of the Silent Generation and Baby boomers in most cases are completing their working career and retiring, while representatives of Generation $X$ are at their highest position in profession, and representatives of Generations $\mathrm{Z}$ and $\mathrm{Y}$ are just beginning their career.

To determine the generation differences in the teachers' motivation for professional activity we used the methodological approach of J. Barbuto and R. Skoll and singled out five groups of motives. They are internal motives that focus on the process, selfimprovement and self-realization; external motives that include reward and approval of others; integrative motives that coordinate the goals of an individual employee with the goals of the whole staff [12].

The first important group of motives includes the system of leading interests and attitudes, the social orientation of a teacher as a representative of society and a performer of an important social task, his/her readiness for professional activity. Considering the importance of their profession in society, most representatives of the Silent Generation expressed themselves quite critically, as $85.5 \%$ of them disagree with the fact that teaching is valued in the modern Ukrainian society. Nevertheless, the others, in particular the teachers of Generations $\mathrm{Y}$ and $\mathrm{Z}$ are more optimistic as correspondingly $42.2 \%$ and $57.2 \%$ of them believe that the teacher's job is socially important.

However, despite the fact that the majority of respondents like to work at school, there is a certain ambiguity in their thoughts, namely, among representatives of the youngest group because they are the most dissatisfied with their choice of profession. On the other hand, the predominance of the conscious choice of the profession is also confirmed by the fact that $87.4 \%$ of respondents agree fully or partially with the statement that the advantages of teaching career outweigh disadvantages. Indeed, teachers can be compared with altruists who refuse public recognition consciously in favour of favourite occupation, because for most of them it is not just a profession, but also a way of life (see tab. 1).

Table 1. Distribution of answers to the question 'Do you agree with the statement that teacher is appreciated in the society?' (\%, of the total number of respondents).

\begin{tabular}{|c|c|c|c|c|c|}
\hline & 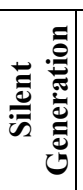 & 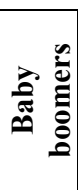 & 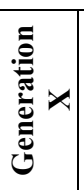 & 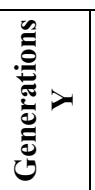 & N \\
\hline \multicolumn{6}{|c|}{ In my opinion, teacher as a job is appreciated in the world } \\
\hline Completely disagree & 28.6 & 14.9 & 16.4 & 12.9 & 14.3 \\
\hline Disagree & 57.1 & 51.3 & 56.8 & 44.3 & 28.6 \\
\hline Agree & 14.3 & 25.4 & 22.3 & 54.7 & 42.9 \\
\hline Completely agree & 0 & 6.6 & 4.5 & 8.1 & 14.3 \\
\hline \multicolumn{6}{|c|}{ If I had to choose, I would choose teaching again } \\
\hline Completely disagree & 0 & 2.3 & 2.9 & 5.5 & 0 \\
\hline Disagree & 14.3 & 7.8 & 16.3 & 20.2 & 28.6 \\
\hline Agree & 50.0 & 50.6 & 57.1 & 58.1 & 57.1 \\
\hline Completely agree & 35.7 & 39.3 & 23.6 & 16.2 & 14.3 \\
\hline \multicolumn{6}{|c|}{ Advantages of teaching outweigh disadvantages } \\
\hline Completely disagree & 7.1 & 1.7 & 1.7 & 2.2 & 0 \\
\hline Disagree & 0 & 8.1 & 13.5 & 14.9 & 14.3 \\
\hline Agree & 78.6 & 68.5 & 71.2 & 69.07 & 71.4 \\
\hline Completely agree & 14.3 & 21.7 & 13.7 & 13.3 & 14.3 \\
\hline \multicolumn{6}{|c|}{ I like working at this school } \\
\hline Completely disagree & 0 & 1.7 & 1.3 & 1.9 & 0 \\
\hline Disagree & 7.1 & 3.6 & 4.4 & 5.7 & 0 \\
\hline Agree & 57.1 & 45.9 & 56.8 & 58.1 & 28.6 \\
\hline Completely agree & 35.7 & 48.7 & 37.5 & 43.7 & 71.4 \\
\hline
\end{tabular}

It is quite logical that certain doubts about the level of readiness for professional activities are more peculiar to young teachers, primarily due to the lack of experience (see table 2). Since they consider themselves prepared in terms of content filling of 
subjects, but have doubts about the methods of teaching and the progress of teaching practice. For teachers of Generations $\mathrm{X}, \mathrm{Y}$ and $\mathrm{Z}$, there is a positive trend to age reducing, which can evidence qualitative changes in the process of training specialists in higher education institutions, increasing the effectiveness of professional development activities etc. However, these assumptions require further studying.

Table 2. Distribution of answers to the question 'How prepared are you to the points in your teaching given below?' $(\%$, of the total number of respondents).

\begin{tabular}{|l|c|c|c|c|c|}
\hline & & & \\
& & & \\
\multicolumn{7}{|c|}{ Content filling of subjects that I teach } \\
\hline Completely unprepared & 0 & 7.0 & 6.7 & 3.7 & 0 \\
\hline Prepared to some extent & 0 & 1.6 & 1.5 & 4.4 & 0 \\
\hline Well prepared & 78.6 & 51.0 & 57.5 & 62.2 & 71.4 \\
\hline Very well prepared & 21.4 & 40.5 & 34.2 & 29.7 & 28.6 \\
\hline Methods of teaching subjects that I teach \\
\hline Completely unprepared & 0 & 7.0 & 6.3 & 3.2 & 14.3 \\
\hline Prepared to some extent & 0 & 2.3 & 3.0 & 4.7 & 0 \\
\hline Well prepared & 78.6 & 52.2 & 59.9 & 68.6 & 85.7 \\
\hline Very well prepared & 21.4 & 38.4 & 30.8 & 23.4 & 0 \\
\hline Teaching practice of subjects that I teach \\
\hline Completely unprepared & 0 & 7.0 & 6.5 & 3.1 & 14.3 \\
\hline Prepared to some extent & 0 & 2.1 & 3.5 & 5.9 & 0 \\
\hline Well prepared & 78.6 & 49.7 & 55.1 & 64.7 & 71.4 \\
\hline Very well prepared & 0 & 7.0 & 6.5 & 3.1 & 14.3 \\
\hline
\end{tabular}

Self-improvement and self-realization are important determinants of teacher's professional development. They ensure the expansion of his/her opportunities, interests, and the formation of individuality.

Readiness for self-improvement appears only when a teacher is internally free from any fears, failures, critically evaluates his/her abilities, opportunities, and is aware of the need for change. Silent Generation should urgently improve their skills in working with information and computer technologies. Generation $\mathrm{Z}$ has little experience in assessing student behavior and class guidance. The younger the generation of teachers is, the more they feel the need for professional development in the field of individual learning, working with students with special needs. The archaism of the professional activity of the Silent Generation is a biased attitude towards the possibility of teaching children with physical and mental health disabilities together with healthy children (see table 3 ). However, they actively express their readiness for selfimprovement, as well as representatives of other age groups.

There are no particular differences in age preferences among organizational forms and methods of self-improvement and self-realization, except the tendency of Generation $\mathrm{Z}$ representatives to borrow advanced teaching experience of older colleagues in such forms as scientific, practical teaching conferences and seminars, reference/review visits to enterprises, public and non-governmental establishments. The younger teachers are, the less they need to participate in qualification programs and the more desirable an active practice of sharing experiences through mentoring and/or engaging in learning, participating in the activities of professional associations is.

Table 3. Distribution of answers to the question 'How do you feel the need for professional development in each of the following areas?' (\%, of the total number of respondents).

\begin{tabular}{|c|c|c|c|c|c|}
\hline & Uू & 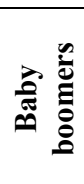 & 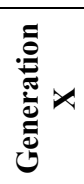 & 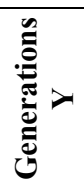 & N \\
\hline \multicolumn{6}{|c|}{$\begin{array}{c}\text { Awareness of the place of the subject in the general training } \\
\text { program }\end{array}$} \\
\hline Not necessary & 35.7 & 58.9 & 46.6 & 48.7 & 50.0 \\
\hline Little necessary & 28.6 & 21.2 & 28.7 & 29.0 & 50.0 \\
\hline Necessary & 28.6 & 16.1 & 20.3 & 19.8 & 0 \\
\hline Very necessary & 7.1 & 3.8 & 4.4 & 2.5 & 0 \\
\hline \multicolumn{6}{|c|}{ Students assessment and assessment approaches } \\
\hline Not necessary & 35.7 & 52.8 & 40.1 & 36.5 & 28.6 \\
\hline Little necessary & 14.3 & 25.5 & 32.6 & 34.8 & 57.1 \\
\hline Necessary & 42.9 & 17.6 & 22.8 & 24.1 & 0 \\
\hline Very necessary & 7.1 & 4.1 & 4.5 & 4.6 & 14.3 \\
\hline \multicolumn{6}{|c|}{ Information and computer technology skills } \\
\hline Not necessary & 14.3 & 10.4 & 15.6 & 34.5 & 50 \\
\hline Little necessary & 7.1 & 27.3 & 32.1 & 33.6 & 50 \\
\hline Necessary & 42.9 & 44.8 & 36.2 & 23.9 & 0 \\
\hline Very necessary & 35.7 & 17.4 & 16.0 & 8.1 & 0 \\
\hline \multicolumn{6}{|c|}{ Students behavior and class guidance } \\
\hline Not necessary & 42.9 & 46.9 & 34.9 & 23.1 & 0 \\
\hline Little necessary & 21.4 & 29.3 & 32.7 & 37.9 & 57.1 \\
\hline Necessary & 28.6 & 20.1 & 25.5 & 30.1 & 42.9 \\
\hline Very necessary & 7.1 & 3.8 & 6.8 & 8.9 & 0 \\
\hline \multicolumn{6}{|c|}{ Individual studying approaches } \\
\hline Not necessary & 64.3 & 39.5 & 26.8 & 23.6 & 28.6 \\
\hline Little necessary & 14.3 & 32.2 & 37.7 & 40.8 & 28.6 \\
\hline Necessary & 21.4 & 24.3 & 31.0 & 30.1 & 28.6 \\
\hline Very necessary & 0 & 4.0 & 4.5 & 5.4 & 14.3 \\
\hline \multicolumn{6}{|c|}{ Teaching students with special needs } \\
\hline Not necessary & 76.9 & 47.6 & 35.8 & 36.8 & 14.3 \\
\hline Little necessary & 7.7 & 22.8 & 27.3 & 25.2 & 57.1 \\
\hline Necessary & 15.4 & 25.2 & 30.2 & 30.9 & 0 \\
\hline Very necessary & 0 & 4.4 & 6.7 & 7.1 & 28.6 \\
\hline \multicolumn{6}{|c|}{ New technologies in the workplace } \\
\hline Not necessary & 21.4 & 9.7 & 8.9 & 14.3 & 14.3 \\
\hline Little necessary & 7.1 & 27.9 & 26.2 & 26.4 & 42.9 \\
\hline Necessary & 64.3 & 48.5 & 45.7 & 42.4 & 28.6 \\
\hline Very necessary & 21.4 & 9.7 & 8.9 & 14.3 & 14.3 \\
\hline
\end{tabular}

The high level of self-motivation confirmed by the fact that almost half of the representatives of the Silent Generation, Generation $Z$ and every fourth representative of the Baby boomers, Generations $X$ and $\mathrm{Y}$ are willing to pay for participating in advanced training activities (see table 4).

Analyzing the existing obstacles to selfimprovement and self-realization, determined by the teachers' estimates, it is noted that the index of the balance of assessments is indicative, which is defined as the difference in percent of positive and negative response options multiplied by a factor of 1 and 0.5 respectively. 
Table 4. Distribution of answers to the question 'What financial basis did your professional development events in which you participated during the last year have?' (\%, of the total number of respondents).

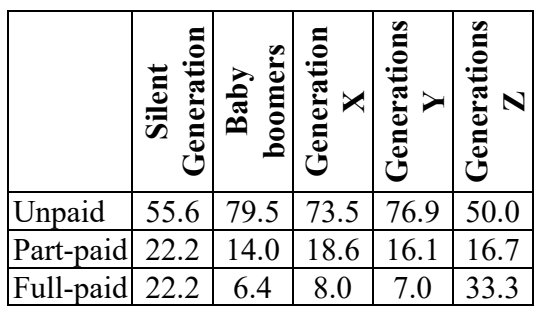

Table 5. Distribution of answers to the question 'How do you agree or disagree with the below mentioned obstacles to your professional development?' (\%, of the total number of respondents).

\begin{tabular}{|c|c|c|c|c|c|}
\hline & 恶 & 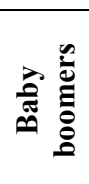 & 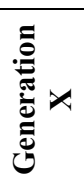 & 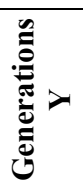 & N \\
\hline \multicolumn{6}{|c|}{$\begin{array}{c}\text { Professional development is too expensive / financially out of } \\
\text { reach }\end{array}$} \\
\hline Completely disagree & 21.4 & 29.9 & 23.9 & 20.0 & 42.9 \\
\hline Disag & 50.0 & 51.4 & 53.3 & 51.8 & 57.1 \\
\hline Agre & 28.6 & 17.5 & 19.7 & 25.5 & 0 \\
\hline Compl & 0 & 1.2 & 3.1 & 2.7 & 0 \\
\hline & -32.1 & -45.7 & -37.6 & -30.5 & -71.5 \\
\hline \multicolumn{6}{|c|}{ No employer support } \\
\hline Completely disagree & 71.4 & 37.0 & 30.4 & 30.3 & 42.9 \\
\hline Disa & 21.4 & 50.4 & 51.7 & 53.6 & 57.1 \\
\hline & 0 & 10.7 & 14.5 & 12.0 & 0 \\
\hline Con & 7.1 & & 3.5 & 4.1 & 104.3 \\
\hline Assessment balance & -75.0 & -54.9 & -45.5 & 47.0 & -71.5 \\
\hline \multicolumn{6}{|c|}{$\begin{array}{c}\text { Professional development programs are implemented during } \\
\text { mv working hours }\end{array}$} \\
\hline Completely disagree & 23.1 & 16.3 & 11.5 & 10.9 & 42.9 \\
\hline & 0 & 1.7 & 36.1 & 32.7 & 14.3 \\
\hline & 61.5 & 43.3 & 45.9 & 48.5 & 42.9 \\
\hline Co & 5.4 & 8.8 & 6.5 & 7.9 & 0 \\
\hline Assessment balance & 23.1 & -1.7 & -0.1 & 4.9 & -28.6 \\
\hline \multicolumn{6}{|c|}{ I don't have time because of family obligations } \\
\hline Completely disagree & 50.0 & 41.4 & 28.0 & 28.1 & 57.1 \\
\hline & 50.0 & 51.6 & 57.8 & 56.3 & 42.9 \\
\hline & 0 & 5.5 & 12.7 & 14.3 & 0 \\
\hline Comple & 0 & 1.5 & 1.5 & 1.3 & 0 \\
\hline Assessment balance & -75.0 & -63.0 & -49.1 & 47.8 & -78.6 \\
\hline \multicolumn{6}{|c|}{ No corresponding professional development programs } \\
\hline & 28.6 & 31.9 & 24.4 & 20.8 & 28.6 \\
\hline & 50.0 & 53.1 & 55.7 & 56.6 & 57.1 \\
\hline & 21.4 & 13.4 & 17.0 & 19.9 & 0 \\
\hline Completely a & 0 & 1.6 & 2.8 & 2.7 & 14.3 \\
\hline Assessment balance & -42.9 & -50.2 & -41.0 & -36.5 & -42.9 \\
\hline \multicolumn{6}{|c|}{ No reward for participating in such events } \\
\hline Completely disagree & 28.6 & 19.3 & 12.2 & 12.2 & 28,6 \\
\hline Disagree & 28.6 & 41.2 & 34.9 & 32.6 & 28,6 \\
\hline Agree & 21.4 & 30.5 & 39.0 & 40.9 & 28,6 \\
\hline Completely agree & 21.4 & 9.0 & 13.9 & 14.3 & 14,3 \\
\hline Assessment balance & -10.8 & -15.7 & 3.8 & 6.3 & $-14,3$ \\
\hline
\end{tabular}

For representatives of the Silent Generation, the biggest obstacles for professional development are the inconsistency of their time (most professional development programs are implemented during my working hours), which leads to disruption of the educational process, and the lack of stimulation of participation in such events by school authorities. The younger the teachers are, the less they care about the fact that professional development events are carried out during working hours. For representatives of Generations $\mathrm{X}$ and $\mathrm{Y}$ a more significant obstacle to self-improvement than for others is the lack of reward for participation in such events, as well as the lack of time because of family obligations (see table 5).

As for the last group of motives, namely the consistency of the goals of a particular teacher with the goals of the teaching staff, we should note that the majority have the opportunity to participate in school management on a democratic basis. Only the more ambitious representatives of Generations $\mathrm{X}$ and $\mathrm{Y}$ have some doubts. The majority of respondents also agree that an atmosphere of mutual understanding and mutual assistance prevails at schools where they work (see table 6).

Table 6. Distribution of answers to the question 'How do you agree or disagree with the statements about your school?'

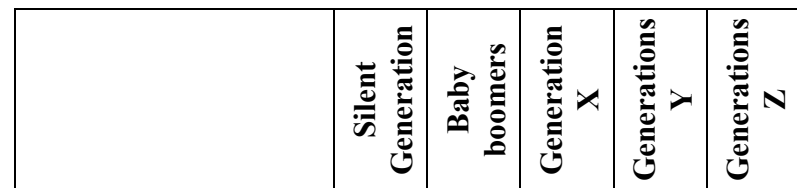

The school gives teachers the opportunity to take an active part in making decisions about the school

\begin{tabular}{|l|c|c|c|c|c|}
\hline Completely disagree & 7.1 & 2.7 & 3.3 & 2.4 & 0 \\
\hline Disagree & 0 & 7.9 & 15.2 & 17.6 & 0 \\
\hline Agree & 71.4 & 66.4 & 67.6 & 70.2 & 71.4 \\
\hline Completely agree & 21.4 & 23.1 & 14.0 & 9.9 & 28.6 \\
\hline $\begin{array}{c}\text { There is a common school culture characterized by mutual } \\
\text { help and mutual support }\end{array}$ \\
\hline Completely disagree & 7.1 & 1.7 & 1.9 & 1.8 & 0 \\
\hline Disagree & 14.3 & 8.5 & 9.2 & 11.8 & 0 \\
\hline Agree & 71.4 & 63.9 & 69.5 & 68.9 & 100 \\
\hline Completely agree & 7.1 & 26.2 & 19.5 & 17.5 & 0 \\
\hline
\end{tabular}

Among other motives of professional activity, one should pay attention to the motives of having selfprofit (material satisfaction and approval from others). Thus, answering the question about how the results of the assessment of professional activity influenced the official recognition by the head teacher and colleagues, all respondents of Generation $\mathrm{Z}$ noted positive changes, almost every seventh teacher of Generations X, Y and Baby boomers noted minor changes. In the opinion of half of the respondents, despite the positive assessment of the activity, their success brought no payment rise nor career advancement. However, most teachers think that the results of the assessment increase their selfconfidence and work enjoyment, as well as strengthen professional activity motivation. This fact confirms conscious internal motivation for professional activity prevailing in most teachers of Silent Generation and Generation Z, and peculiar to almost half of representatives of Generations X, Y and Baby boomers (see table 7). 
Table 7. Distributions of answers to the question 'How do obtained results of your professional activity assessment influence positively the following?' (\%, of the total number of respondents).

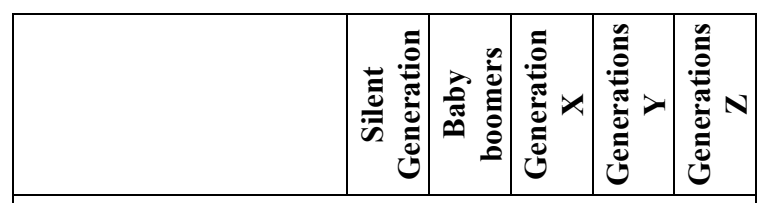

Official recognition by the head teacher and/or colleagues \begin{tabular}{|l|c|c|c|c|c|}
\hline No positive changes & 0 & 2.3 & 3.4 & 3.8 & 0 \\
\hline A
\end{tabular} \begin{tabular}{|l|c|c|c|c|c|}
\hline A little bit & 15.4 & 11.2 & 15.4 & 12.9 & 0 \\
\hline
\end{tabular}

\begin{tabular}{|l|c|c|c|c|c|}
\hline Moderately & 69.2 & 40.2 & 40.4 & 43.4 & 83.3 \\
\hline A lot of influence & 15.4 & 46.3 & 40.8 & 39.9 & 16.7 \\
\hline
\end{tabular}

\begin{tabular}{|l|l|l|l|l|l|}
\hline A lot of influence & 15.4 & 46.3 & 40.8 & 39.9 & 16.7 \\
\hline
\end{tabular} Career development opportunity

\begin{tabular}{|l|l|l|l|l|c|}
\hline No positive changes & 23.1 & 14.3 & 12.2 & 13.0 & 0 \\
\hline A lite bit & 46.2 & 27.3 & 23.3 & 21.8 & 16.7 \\
\hline
\end{tabular}

\begin{tabular}{|l|c|c|c|c|c|}
\hline A little bit & 46.2 & 27.3 & 23.3 & 21.8 & 16.7 \\
\hline Moderately & 30.8 & 31.0 & 36.5 & 39.0 & 66.7 \\
\hline
\end{tabular}

\begin{tabular}{|l|c|c|c|c|c|}
\hline Moderately & 30.8 & 31.0 & 36.5 & 39.0 & 66.7 \\
\hline A & 0 & 27.3 & 28.0 & 26.2 & 16.7 \\
\hline
\end{tabular}

\begin{tabular}{|l|c|c|c|c|c|}
\hline A lot of influence & 0 & 27.3 & 28.0 & 26.2 & 16.7 \\
\hline \multicolumn{2}{|c|}{} \\
\hline
\end{tabular}

Your self-confidence as a teacher

\begin{tabular}{|l|c|c|c|c|c|}
\hline No positive changes & 7.7 & 2.2 & 3.0 & 2.7 & 0 \\
\hline A & 30.8 & 9.4 & 11.3 & 12.1 & 16.7 \\
\hline
\end{tabular}

\begin{tabular}{|l|c|c|c|c|c|}
\hline A little bit & 30.8 & 9.4 & 11.3 & 12.1 & 16.7 \\
\hline Moderately & 46.2 & 38.3 & 40.7 & 37.0 & 66.7 \\
\hline
\end{tabular}

\begin{tabular}{|l|c|c|c|c|c|}
\hline Moderately & 46.2 & 38.3 & 40.7 & 37.0 & 66.7 \\
\hline A lot of influence & 15.4 & 50.2 & 45.0 & 48.2 & 16.7 \\
\hline
\end{tabular}

Your salary and/or premium

\begin{tabular}{|l|l|l|l|l|l|}
\hline No positive changes & 15.4 & 15.6 & 20.6 & 25.0 & 16.7 \\
\hline A litte bit & 7.7 & 27.1 & 31.8 & 31.9 & 16.7 \\
\hline
\end{tabular}

\begin{tabular}{|l|c|c|c|c|c|}
\hline A little bit & 7.7 & 27.1 & 31.8 & 31.9 & 16.7 \\
\hline
\end{tabular}

\begin{tabular}{|l|c|c|c|c|c|}
\hline Moderately & 61.5 & 36.2 & 33.0 & 30.7 & 50.0 \\
\hline A lot of infuence & 15.4 & 20.2 & 15.6 & 12.4 & 16.7 \\
\hline
\end{tabular}

\begin{tabular}{|l|l|l|l|l|l|}
\hline A lot of influence & 15.4 & 20.2 & 15.6 & 12.4 & 16.7 \\
\hline
\end{tabular} Your pleasure from work

\begin{tabular}{|l|c|c|c|c|c|}
\hline No positive changes & 7.7 & 2.9 & 4.8 & 6.3 & 0 \\
\hline A little bit & 23.1 & 10.2 & 14.8 & 13.9 & 0 \\
\hline Moderately & 53.8 & 46.7 & 48.1 & 43.5 & 50.0 \\
\hline A lot of influence & 15.4 & 40.2 & 32.2 & 36.3 & 50.0 \\
\hline \multicolumn{5}{|c|}{ Your motivation } \\
\hline No positive changes & 7.7 & 3.7 & 5.8 & 6.9 & 0 \\
\hline A little bit & 30.8 & 14.1 & 16.3 & 10.7 & 33.3 \\
\hline Moderately & 46.2 & 45.3 & 45.7 & 43.6 & 33.3 \\
\hline A lot of influence & 15.4 & 35.9 & 32.2 & 38.8 & 33.3 \\
\hline
\end{tabular}

\section{Conclusions and generalizations}

Summarizing the results, we should note that representatives of the Silent Generation and Baby boomers are completing their professional pass; teachers of Generations $\mathrm{X}$ and $\mathrm{Y}$ are at their peak of teaching career while Generation $Z$ is taking the first steps in the professional field. Each of these generations has its own archetype manifested in the professional activity motivation. Representatives of Generation $\mathrm{Z}$ adapt actively to the conditions of professional activity; young teachers have a certain amount of knowledge but do not have any sufficient practical experience in its application. Teachers of Generation $Y$ have a stable professional activity, formed personal position, awareness of the desire for self-realization, and the desire to improve teaching skills. Most teachers of Generation $X$ have a psychological crisis, connected with the awareness of the contradictions between their desire for selfimprovement and the real opportunities of teaching. Baby boomers are characterized by a high level of development of professionally significant qualities, stability in socio-economic terms, self-confidence, and confidence in teaching skills. Teachers of the Silent Generation are distinguished by the combination of biological and professional aging, manifested in the rejection of innovation, the violation of partnership with students and colleagues, and psycho-emotional overstrain.

Compared to others, teachers of Generations $\mathrm{X}$ and $\mathrm{Y}$ are especially distinguished where the external motivation of professional activity prevails, but the representatives of the Silent Generation, Baby boomers and Generation $Z$ are determined by internal motivation. However, teachers of Generation $\mathrm{Y}$, in their opinion about self-improvement and selfrealization, are closer to Generation $\mathrm{Z}$ than to Generation $X$. At the same time, there are positive trends in changes in the culture of self-determination and self-affirmation of representatives of different generations of teachers towards the development of innovative means and forms. In addition, we can see the liberalization of attitudes towards special children, which is of great importance under the conditions of the development of an inclusive component of modern national education.

In the national practice of managing the teaching staff of the school, the adaptation of the main aspects of generations' theory, taking into account the value approach, will make it possible in the long-run to implement effective management in school based on humanistic paradigm. Taking into account the generation differences, we advise to use the following methods of non-material motivation for professional activity within a person-oriented approach towards representatives of different generations. For the representatives of the Silent Generation this means ensuring stable social status, guarantees of social package, respect and reverence by students, parents, colleagues, and school authorities. For Baby boomers, it is the interest in personal development, team cohesion, friendly relations and the desire for innovation. For Generation $\mathrm{X}$ this means the prospect of self-realization and career growth, the desire to learn continuously. For Generation $\mathrm{Y}$ it is the realization of creative potential, providing opportunities for learning and development. For Generation $\mathrm{Z}$ this implies sharing experience, evaluation of individual achievements, as well as the opportunity to receive real-time feedback and participate in the management of an educational institution democratically.

Under the conditions of reforming the secondary education system in Ukraine, the implementation of innovations in school management is impossible without strengthening the role of teachers as subjects of the educational process, forming partnerships between all management subjects, taking into account the specific conditions of the educational process, the number of students and the personnel potential of a particular school. It is necessary to introduce reforms in the education system, predominantly relying on Generation Z, as the part of the teachers' community most open for communication and interaction. Nevertheless, it is also necessary to take into account 
the experience of mature generations, since they can teach young people purposefulness and creativity in solving difficult professional tasks.

\section{Reference}

1. L. Novikova, Value differences of generations in the modern Ukrainian society. Bulletin of Kyiv national University named after Taras Shevchenko. Sociology 1, 23-31 (2015)

2. L. Kalinina, L. Karamushka, T. Sorochan, R. Shiyan, Osvitnij menedzhment $v$ umovax zmin (Educational management in changing environment), ed. by V. Oleinik, N. Protassova (National Academy of pedagogical Sciences of Ukraine, Institute of management education, Lugansk regional Institute of postgraduate pedagogical education, Lugansk, 2011)

3. V.A. Yadov, Samoreguljacija i prognozirovanie social'nogo povedenija lichnosti: Dispozicionnaja koncepcija (Self-regulation and forecasting of social behavior of personality: Dispositional concept). (Center for Social Forecasting and Marketing, Mocsow, 2013)

4. I. Bekh, The willingness of the teacher to innovative activity. Bulletin of Zhytomyr state pedagogical university 13, 3-8 (2003)

5. Iu.N. Kuliutkin, V.P. Bezdukhov, Cennostnye orientiry $i$ kognitivnye struktury $v$ dejatel'nosti uchitelja (Value orientations and cognitive structures in the teacher's activity). (Samara state pedagogical university, Samara, 2002)

6. W. Strauss, N. Howe, The history of America's, 1584 to 2069 (William Morrow and Company, New York, 1991)

7. M.H. Titma, E.A. Saar, The young generation (Mysl, Moscow, 1986)

8. B.C. Urlanis, The History of one generation (socio-demographic survey) (Mysl, Moscow, 1968)

9. Y.A Levada, Pokolenija XX veka: vozmozhnost' issledovanija, Otcy $i$ deti: Pokolencheskij analiz sovremennoj Rossii (Generation of the twentieth century: the possibility of research, Fathers and sons: Generational analysis of modern Russia). (New literary review, Moscow, 2005), pp. 39-60

10. V. Pischik, The mentality of the generations in the current of modernity (Infra-M, Moscow, 2019)

11. S. Shchudlo, O. Zabolotna, T. Lisova, Ukrainian Teachers and the Learning Environment. Results of All-Ukrainian Monitoring Survey of Secondary School Teachers and Principals (by the TALIS methodology) (Trek LTD, Drohobych, 2018)

12. J.E. Barbuto, R.W. Scholl, Motivation sources inventory: development and validation of new scales to measure an integrative taxonomy of motivation. Psychological Reports 82(3) (1998)
13. T.P. Bliznyuk, Theory of generations in personnel management. Theoretical and practical aspects of Economics and intellectual property 14, 112-117 (2016)

14. V.A. Rozanov, Psihologija upravlenija (The psychology of management). (Business school Intel-Synthesis, Moscow, 1999) 